DOI: https://doi.org/......

УДК 726.5 .03

EDD, Full Professor Flores-García LauraGemma

flores_gemma@hotmail.com, https://orcid.org/0000-0002-7405-4883 PhD and Licensed Doctor, Full Professor Zhizhko Elena Anatolievna eanatoli@yahoo.com, https://orcid.org/0000-0001-9680-8247

Autonomous University of Zacatecas, Mexico

\title{
NOVOHISPANIC CONVENT ARCHITECTURE FROM THE 16th CENTURY
}

Abstract: The article presents the results of a historical and architectural research, which aimed to reveal the main features of the architecture of Spanish monasteries in the sixteenth century, in particular to highlight elements of the ideology of the Spanish crown and the Catholic Church, promoted through architectural structures. The authors established the components of the architectural program and styles of the New Spanish monasteries of the 16th century, highlighted how the process of creative thinking of the future building and its construction took place, what materials were used.

Key words: historical and architectural research; 16th century architecture; architecture of New Spanish monasteries; architectural program and styles in colonial Mexico.

Problem's formulation. Cortés asked Moctezuma, if he gold has, and he answered: "I do". "Send it to me". He says: "Some of it, because my people and I have heartache, and disease that can be healed with it" [5]. This was the main movement for the conquest of Mexico. However, the fundamental reasons that was argued by the Pope, the King and all his subjects, was to fulfill with the Christ's task, which was given to his "twelve" at the beginning of the Christian era: "Go ye into all the world, and preach the gospel to every creature" [1].

The Franciscan friars, who observed the Spanish Renaissance Period, were believers of that too, they were eager to practice the same as in Spain, with such a mosaic of cultures, and points of view it was practically impossible to perform.

Notwithstanding, the methods of good intentions, sanity and a proper treatment to indigenous people in the working environment and labor, not always were not consistent with the tenets of their religion. We know that up to 1550 there was forced labor that would be paid until the last quarter century. In this moment, by almost explicit intervention of Fray Bartolomé de las Casas in his terrible discussions against Fray Ginés de Sepúlveda, an attempt to create a paid volunteer work reservation appears [8]. 
Because the transfer of materials was so expensive, there was determinations that did not affect the indigenous people at that time, much less to the friar desirous of disappearing all vestiges of idolatry and false religion. Then, they resorted to reusing the material that had already been used in works from the Prehispanic times. That was the case of the construction of the Franciscan church of Tlaxcala, in which the stones of the façade had been part of a Prehispanic temple.

The friars chose places according to different natural characteristics in order to reduce the labor force; therefore, they settled in areas of high concentration of indigenous people and abundant appropriate materials for building. That was the "Mextitlán" zone case where George Kubler says that there we can find the best stone for construction from all over Mexico. Ixmiquilpan, Tula and Actopan were due to the enormous abundance of stone. Within the characteristics of these building materials we must point out that there was two types of stones that in the 16th century were the most used: tezontle (a porous, highly oxidized, volcanic rock) and the tecali (onyx), and in Tecamachalco, the black tezontle.

The mexican tecali-onyx was plenty in the Prehispanic Mexico. It was a thin stone and it would become in a sumptuous substitute for window glass. Regarding to gluing materials, the limestone mortar was very expensive, and that's why sometimes they used a substitute. George Kubler (1986) says that as passive resistance the indigenous people began to use ash, causing the collapse of the vaults or the walls and they had to rebuilt them [3;4]. Although to replace the lime, most of the time rammed earth and adobe coated with stone slab were used together with adobe and fodder (or straw) as an additive. Finally, the materials resources were simply circumstantial regarding the entire ideological foundation that the Spanish crown promoted through its mendicant orders.

The purpose of this work is identify, how happened the process of creation, production and worship of the novohispanic convent architecture in the 16th century, highlighting the components of the architectural program and styles, as well as the elements of the Spanish crown's and Catholic Church's ideology promoted through architectural works.

\section{The main material.}

The philosophical-theological foundations of colonial art. The philosophical climate that prevailed at this period was the product of scholastic thinking that preached the utilitarian value of the piece of art, rather than artistic. This was pointed out by Saint Thomas in his writings. The works only served as transmitting objects for the moralizing messages of the church.

Another cause that shaped New Spanish art was the fees emitted by the Council of Trent in its 25 th session from 1563 regarding the production and worship of sacred images and summarized in four essential points applied to the sculpture and painting: 
honesty in the representation of the images; absolute censorship for the unusual images and the superstitious implications; emphasis in the didactic function and symbolic value of the images.

The most used books of the Bible for the realization of convent program were the ones where the paradise was discussed (Genesis); the revealed construction plans for the tabernacle and Solomon temple (Exodus); and the division of Israel tribes into four squares around the Tabernacle (Numbers). It's possible that other sources were used too, like the Antiques of Flavio Josef (that includes a diligent description of Jerusalem Herodias Temple, where Jesus and his disciples used to gather); Constantine's Life and The Ecclesiastical History of Eusebius Pamphilus, with descriptions of the Holy Land churches.

Consideration for the revealed plan for Solomon's Temple and representative images from the militant church coherently intervened in the program of the convent as a building and also as part of the orientation that evangelization took. Frequently the construction friars were compared with Moses and Solomon or with the biblical artifices that put in motion the revealed plans, like Bezalel, Hiram and Zerubbabel. In second term, the presence of platforms protected by walls, battlements, buttresses crowned with modillions, of paths of round and of friezes full of shields, either low or with Christian emblems, Marians or the orders that finish off the walls of the churches, chapels inns and doorways of many convents or that are part of the compositions based on grotesques, respond to the defensive images of the militant church and drop repeated biblical antecedents.

The indigenous people not always understood this profound reasons to build in this or that way, but they always followed the patterns of the Spanish alarifes and once in a while- they didn't forgot to considerate on those well-kept iconographic programs the appearance of one of their idols, of some of their symbols or one of their many cosmovisions that, curiously and inexplicably, matched withe the European proposals, but they had nothing to do with them and for that reason were accepted, before the innocent gaze of the friaries heroes.

Traders and masters of works in the 16th century convent architecture. Viceroy Antonio de Mendoza kept among his belongings architecture books, which he always kept his notes. Perhaps in his eagerness to make New Spain a center of diffusion and reception of the art of that time, he always said that in all the territory there was no man capable of carrying out the great undertaking of building for prosperity.

Truth is that since very early in New Spain circulated the great works of the European traders that had spread throughout the medieval and renaissance period. The earliest known news about sending architectural treaties dates from 1584, when the bookseller of Medina de Campo, Benito Boyer, send Diego Navarro Maldonado to Mexico, forty boxes of books that included two copies of Serlio among them. Two 
copies of the Castilian translation of Leon de Bautista Alberti works were sent in 1586. Three years later was sent to the Peru a special and spectacular consignment for its time, no less than three hundred copies with ten stamps each on about the designs and traces of the Royal Monastery el Escorial, for Juan de Herrera had requested permission to sell his work in the Indies. Also circulated: "On Architecture by Vitrovius; Serlio's Regole Generali di Architettura; Alberti's De re aedificatoria; Diego Sagredo's Medidas del Romano (that is, Vitrovius)".

These sources plus other vernacular manufactures; Claudio de Arciniega's Imperial tumulus; architectural parties and diverse plans imported from all over Europe, were the works that fueled the learning and mastery of architects such as Don Toribio de Alcaraz, work supervisor during the Mendoza period; Diego Dias de Lisboa that arrived to New Spain in 1526, masonry teacher and master builder in the viceroyalty capital of 1531-1535; Rodrigo Pontesillas, artisan in the building of Mexico city (1527); Martin Sepulveda, master builder named by Cortes (cathedral and royal houses) of supplying the city [7].

To these illustrious men, we must add the members of the orders that were at the same time evangelizing friars, conciliators between ethnic groups, defenders of indigenous people against the Spanish and builders of true architectural wonders. Such are Fray Juan de San Miguel, a Franciscan, who worked around the Michoacán zone; Fray Martin de Valencia, also a Franciscan, who worked in Oaxaca and Tlaxcala; Fray Juan de Alameda (OFM), who evangelized and erected temples around Huejotzingo, Tula and Huaquechula; Fray Francisco de Tembleque (OFM), who participated in the aqueduct of Zempoala to Otumba; Fray Diego de Martin de la Coruña, in Tzintztuntzan; Fray Juan de San Miguel in Uruapan and Fray Juan de Sevilla, Fray Antonio de Roa in Meztitlan high mountain range; as well as Fray Pedro de Gante, who developed in the Mexico Valley.

George Kubler [4] also considers what he calls entrepreneurs and that we consider as drivers of constructions among whom are: Pedro de Gante, Fray Juan de Alameda, Fray Jeronimo de Mendieta, Fray Alonso de la Veracruz, Fray Andres de Mata (he participated in the constructions of Actopan and Ixmiquilpan), Fray Vicente de Santa Maria, Fray Melchor de los Reyes among others. All of them collaborated in the magnanimous task of leaving for posterity the architectural wonders that we know today. Let's see what the original plan of the architectural party was and what each thing worked for.

Components of the architectural program. Firstly, it is common for the building as a citadel that stands on a natural or artificial mound (on occasions of prehispanic origin) with the ground leveled in one or more planes, ensuring a flat and rectangular surface clearly protected by thick walls, most of which are crenellations, that surround it. Access to the atrium, called in some documents as processional courtyard 
or compass, can be triple, the main one being located to the west, in axis with the church main gate, and the other two, also in axis-oriented to the north and south, respectively. In general, the intersection of the axes was reserved for the atrial cross and each corner of the processional courtyard for a chapel inn, communicated through platforms delimited by trees or low walls.

The eastern section of the great enclosure was dedicated to the church, the open chapel, which nave is the atrium itself, the baptistery, attached either to the church or to the convent doorway, the school for indigenous kids (sons of chieftains and principals) and the convent, where all the dependencies are developed around the cloister. The latter is accessed through a portico, more or less elaborated; which sometimes extends to into another portico area located at a right angle, commonly called the pilgrim's portico. The land located in the rear part of the church and the convent was dedicated to the stable, the orchard and the cisterns.

The church, generally a single nave without a transept, expresses through its volumetric solution a massive, grandiose and robust character. The walls are only broken with the reinforcing walls that in many Franciscan convents adds twelve; the parapet walk, as in the convents of Cuauhtinchan and Tepeaca; the upper friezes decorated with shields, clypeus or crosses, of which those of Cholula or Atlixco are an example; the modillions and the battlements exemplified in Actopan, Cholula, Tepeaca or Tula [10].

In the convent architecture of the 16th century the question of the traditional liturgical orientation (east-west) played an important role, with the main doorway of the church to the east, and in accordance with the provisions in force since the Constantine era of the 4th century. However, the west doorway was not the only access to the interior of the church, since in most cases exists another one that opens to the north part of the atrium and one in the south that communicates with the cloister.

The one nave church was characteristic of the evangelization; the main chapel and the presbytery, in the front of the church, were generally as wide as the nave according by the laws- but they were separated from it by a large main arch, called triumphal and at a higher level, by access stands. The lighting system was carried out by means of few and very high windows. Most of the early ceilings were made of wood -saddlebags or coffered ceilings, but given the flammability and susceptibility to deterioration, the vaulting, both barrel as ribbed, was adopted, always marking through design variants, the tripartite character of the church.

The sacristy was placed in the presbytery, occasionally the baptistery was incorporated into it, and in some cases it functions as chapter house. The open chapel along with the poses points towards the solution of the needs of the cult on the outdoors in the occasions when the quota of the church was insufficient. 
Lastly, if the convent has two floors, the ground floor was made of portico, lobby (which on occasions could have served as a chapter house), cloister, deep room, a refectory, kitchen, a pantry and other rooms; while the upper floor, strictly reserved to the friars, corresponds to cells, bookstore, direct access to the church choir, etc. Nevertheless, within these principles, the architectural patterns did not strictly adhere to a model, and the same happened with the styles so varied in this small span of architecture life in Mexico.

Architectural styles. In Latin America, Renaissance art was manifested late, although with prominent Hispanic characters. Traditionally, this phase of architecture in the Hispanic world has been classified as plateresque, but Santiago Sebastián (1985) says, such a designation is inaccurate and implies a certain pejorative sense [9]. The Protorenaissance was a common phenomenon in much of Europe because the general sources were Rome and Lombardy. The architects and decorators from the lake region spread not only in Italy but also in Spain, Germany and France, Russia, Poland, Austria, Bohemia and Hungary the decorative repertoire of the Quattrocento. This style would have a great diffusion in America.

The Protorenaissance was inspired for the decorative repertoire in the anticlassical ornamental trend already existing in the Ancient times. Vitruvius stated it as follows: "For instance, reeds are put in the place of columns, fluted appendages with curly leaves and volutes, instead of pediments, candelabra supporting representations of shrines, and on top of their pediments numerous tender stalks and volutes growing up from the roots and having human figures senselessly seated upon them; sometimes stalks having only half-length figures, some with human heads, others with the heads of animals. Such things do not exist and cannot exist and never have existed" [6].

This heterodox ornamentation became fashionable in the fifteenth and sixteenth centuries, receiving the name of grotesque. Grotesque, in the hands of the Spanish, served to cover column shafts, pilasters, archivolts, friezes, panels, etc., generally presenting a composition a candelieri, in other words, starting from an axis or candlestick decorated with a series of vegetable elements, bugs or monstrous beings, already painted or in low reliefs.

That return to the Ancient times that involved the Renaissance appears in the Ordinances of gilders and painters approved by the viceroy Luis de Velasco in 1577. In this document is established that the painters would be examined for their knowledge of the Roman, that is to say, about the Renaissance Art, which was a Rome ancient vocation [2].

The columns in a balustrade form appear not only in the 16th century, but throughout the entire viceregal period. "We shy away from designation", says Sebastián about plateresque supports because the term lacks interest among Hispanic 
American artists [9]. This art was spread through the Bookish Art, prints, cover books, engravings, paintings in altarpieces, book illustrations and drawings from Italy, France and Austria. Moreover, it became the outstanding language of the ornaments in the convent architecture of the 16th century, especially in Augustinian convents such as the case of Acolman, Meztitlán and Yuririapúndaro.

Another style was emerged within the Renaissance until it was personalized as an Anticlassical style. Two of the main characteristics were its relationships with nature and with classical antiquity. The Italian artist went to the ancient sources for the architectural, the figurative and the ornamental. The architectural was visible in the numerous ruins, which buildings Vitruvius had systematized.

Nevertheless, after having found the goal of perfection that the Renaissance achieved during the two decades of the 15th century, the relationship that the artist had with antiquity and nature disappeared. The artist began to interpret them in an increasingly personal way and at this moment, the mannerism emerged. This style consisted in a series of principles, as the principle of duality, which was the most general and characteristic phenomenon and which in turn Rudolf Wittkower (1998) divides in three variants: double function, inversion and permutation [12].

To the head of the series should be the large doorway at the foot of the Actopan convent church that belongs to the architectural pleonasm of the double cover, clear contravention of the basic rules. So, one cover, the top one, it becomes a giant cover; for this reason the stretching or lengthening of the shafts is imposed according to the mannerist principles We have the same phenomenon of the double cover at the lateral entrance of Yanhuitlán church.

The variant of the investment is needed to manifest a construction of more than one floor, so the orders of the shafts can change on the different floors highlighting the view from here to there and impending a joint view from bottom up. Masking was one of the mannerist principles that had the most diffusion in Latin America. Being mannerism a fundamentally contrived style, the simulation was one of their most used principles. The responsible for this phenomenon with mannerist implications was Palladio. He applied the front of a temple to a home residence; with this anticlassical transposition, the house acquired a magnificence that never had.

From the entire phenomenon, that of corruption was the most prominent anticlassical effect. Due to the desire for novelty, licenses were introduced, both in the classical elements and in the syntax of these, which what the Renaissance started losing its exemplary character that had achieved. If Renaissance kept the balance of the equation support-weight, mannerism solved in favor of heaviness, which came to be a consecutive principle, showing some architectural compositions a characteristic dissonance. 
The Mexican historian Elisa Vargas-Lugo (1986) in her work Las portadas religiosas en México took care to organize the cover styles of the religious architecture and divided them in five groups:

1. The primitive forms: they lack ornamental style, the most elemental and scarce style and not necessarily the older, where neither the door openings nor the choir window display any kind of decoration nor even in their jambs.

2. The ones that present combinations in a hybrid way, meaning Tequitqui: style that includes medieval, mudejar and classical elements, many of them took from the covers and engravings of books. Professor John Ma Andrew called this art Tequitqui, term coined by Moreno Villa.

3. The plateresque form: which we have talked about above and we will not abound for obvious reasons.

4. Purist and herrerian forms: the humanistic art, the supreme elegancy, the perfect correction and restraint. It's a style that doesn't admits influences from any other.

5. The classicist or academic forms: the one that freely combines classicist forms, sometimes approaching to the plateresque style and sometimes to the purism style, but that is neither one thing or the other because it shows certain distortions and alterations that make it in some way mannered [11].

Conclusions. Both in architecture and in the sculptural and pictorial manifestations of Mexico in the 16th century, stylistic affiliations can be found from Europe and western culture. If we tried to recover the properly indigenous contributions, maybe we should go to conceptual coincidences like the rite, the space, the sacred, and the fusion of nature with materials transformed by human being. However, certainly, with respect to the structures, the models, stylistic canons and architectural patterns the classical forms will continue to prevail in their bluntest sense, although giving rise to many variations as we demonstrated citing the work of Vargas-Lugo.

\section{References}

1. ACTOPAN (1978). Guía oficial, México: SEP-INAH, Instituto Nacional de Antropología e Historia, $280 \mathrm{p}$.

2. Barrio-Lorenzo F. (1920). Ordenanzas y Gremios de la Nueva España, México: Secretaria de Gobernación, $165 \mathrm{p}$.

3. Kubler G. (1992). Arquitectura mexicana del siglo XVI, México: Fondo de Cultura Económica, 426 p.

4. Kubler G. (1986). Mano de obra indígena en la construcción eclesiástica, en Bauer, A.J. (Comp.) La iglesia en la economía de América Latina, siglos XVI al XI, México: INAH, pp. 131-156. 
5. López-de-Gómara F. (1954). Historia General de las Indias, 2 vols., Barcelona: Ed. Porrúa, 468 p.

6. Los Diez Libros de Arquitectura (2008). Marco Lucio Vitruvio Polion, Libro IV, Madrid: Ed. Alianza.

7. Ricard R. (1986). La Conquista Espiritual de México, Trad. Ángel Ma. Garibay, México: FCE, 320 p.

8. Rojas P. (1981). Historia General del Arte Mexicano, México: Ed. Hermes, $660 \mathrm{p}$.

9. Sebastián S. (1985). Arte Iberoamericano, Madrid: Ed. Espasa Calpe, 482 p.

10. Toussaint M. (1990). Arte colonial de México, México: UNAM, 530 p.

11. Vargas-Lugo E. (1986). Portadas religiosas en México, México: UNAM, $337 \mathrm{p}$.

12. Wittkower R. (1998). Architectural Principles in the Age of Humanism, 2nd Edition, N.Y.: John Wiley \& Sons.

Аннотация

Флорес-Гарсия Лаура Гемма, профессор отдела гуманитарных наук Автономного университета Сакатекаса, Мексика; Жыжко Елена Анатольевна, профессор отдела гуманитарных наук Автономного университета Сакатекаса, Мексика.

\section{Архитектура новоиспанских монастырей XVI века.}

В статье представлены результаты историко-архитектурного исследования, целью которого было определить основные характеристики архитектуры новоиспанских монастырей XVI века, в частности выделить элементы идеологии испанской короны и католической церкви, которые пропагандировались посредством архитектурных сооружений. Авторы выявили компоненты архитектурной программы и стилей новоиспанских монастырей XVI века, определили, как происходил процесс творческого осмысления будущего сооружения и его постройка, какие материалы использовались. Авторы пришли к выводу, что стилистически, в целом, архитектуру новоиспанских монастырей XVI века можно отнести к западной (в основном, европейской) культуре данного исторического периода. Архитектура этих монастырей, главным образом, отражает ее классические формы (конструкцию, модели, стилистические каноны и архитектурные приемы). Однако, в отдельные образцы монастырских зданий были привнесены элементы культуры коренных индейских народов (детали обрядов, концепция пространства, священное слияние природы с материалами, преображенными человеком и т.д.).

Ключевые слова: историко-архитектурное исследование; архитектура XVI века; архитектура новоиспанских монастырей; архитектурная программа и стили в колониальной Мексике. 
Флорес-Гарсія Лаура Гемма, кандидат історичних наук, професор відділку гуманітарних наук Автономного університету Сакатекаса, Мексика, Жижко Олена Анатоліївна, доктор педагогічних наук, професор відділку гуманітарних наук Автономного університету Сакатекаса, Мексика,

Архітектура новоіспанських монастирів XVI століття.

У статті представлені результати історико-архітектурного дослідження, метою якого було розкрити основні ознаки архітектури новоіспанських монастирів XVI століття, зокрема виділити елементи ідеології іспанської корони та католицької церкви, що пропагувалися через архітектурні споруди. Автори встановили компоненти архітектурної програми та стилів новоіспанських монастирів XVI століття, висвітлили, як відбувався процес творчого осмислення майбутньої споруди та ii будівництва, які матеріали використовувалися. Проведене дослідження дозволило виділити такі п'ять типів релігійної новоіспанської архітектури XVI століття: первісні форми, яким бракує орнаментального стилю, Це найбільш елементарний та рідкісний стиль, не обов'язково античний. Він характеризується тим, що ні на дверних отворах, ані на вікнах хору не використано жодної прикраси, навіть у косяках. Другим типом релігійної новоіспанської архітектури $є$ той, що комбінує у собі в гібридному розумінні різні стилі, включаючи середньовічні, мудехарські та класичні елементи. Це так зване мистецтво текіткі (Tequitqui). До третього типу належить платескна форма. Четвертий включає в себе пуристичні та герреріанські форми. Мова йде про гуманістичне мистецтво, вищу елегантність, досконалу корекцію та стриманість. Це стиль, який не допускає впливу будьякого іншого. Нарешті, класицистичні або академічні форми. Цей стиль вільно поєднує класицистичні форми, іноді наближаючись до стилю плашетки, а іноді до стилю пуризму, проте не $є$ копією жодного з них, оскільки демонструє певні спотворення та зміни, часто виконані дещо манерно. Автори дійшли висновку, що загалом архітектуру новоіспанських монастирів XVI століття можна віднести до стилістичної приналежності західній (в основному, європейській) культурі означеного історичного періоду, відображаючи, головним чином, ï класичні форми (конструкція, моделі, стилістичні канони та архітектурні прийоми). Проте, в окремі зразки монастирських будівель були привнесені елементи культури корінних індіанських народів (деталі обрядів, концепція простору, священне злиття природи з матеріалами, перетвореними людиною, тощо). Однак, безумовно, стосовно конструкцій, моделей, стилістичних канонів та архітектурних зразків класичні форми переважають, хоча і мають багато варіацій. Ключові слова: історико-архітектурне дослідження; архітектура XVI століття; архітектура новоіспанських монастирів; архітектурна програма та стилі в колоніальній Мексиці. 